\title{
LOA DE LA COMEDIA DE MONTJUÏC: UN DIÀLEG BÈL·LIC ENTRE CATALUNYA I CASTELLA
}

\author{
LOA DE LA COMEDIA DE MONTJUÏC: \\ AN ARMED DIALOGUE BETWEEN \\ CATALONIA AND CASTILE
}

\author{
Conxita Domènech \\ University of Wyoming \\ cdomenec@uwyo.edu
}

Resum: En aquest article analitzo la lloa ubicada després de La comedia del marqués de los Vélez (I64I) al fons del Museu d'Història de Barcelona i que suposo, per la ubicació i per l'estil, que el mateix autor les va escriure totes dues amb la intenció que primerament fos representada o bé llegida la lloa i a continuació la comèdia. Pel que fa a la lloa, em dedicaré a l'autor anònim català, i concretament barceloní, que vindicarà la presa d'armes dels catalans, si bé ho farà en llengua castellana. A més, l'autor anònim escollirà el teatre —i no el pamflet propagandísticper difondre la seva ideologia política. D'aquesta manera, la Loa de la comedia de Montjuïc es converteix en l'única obra dramàtica breu catalana de caràcter propagandístic escrita en castellà sobre la Guerra dels Segadors.

Paraules clau: barroc, teatre, pamflets, propaganda, Guerra dels Segadors.

Abstract: This article examines a brief dramatic prelude found after La comedia del marqués de los Vélez (I64I) in the archives of the Barcelona History Museum. Due to its location and style, it seems likely that the same author wrote both the introduction in verse and the play, with the intention that the Loa de la comedia de Montjuïc be performed or read before La comedia del marqués de los Vélez. In this brief dramatic prelude, the anonymous author from Barcelona encourages Catalan citizens to arm themselves for war against Castilian troops, but he composes it in the Spanish language. Moreover, the anonymous author chooses the theatre - and not the propaganda pamphlet - to present his ideological views. Thus, the Loa de la comedia de Montjü̈c becomes the only Catalan short theatrical propaganda piece written in Spanish about the Reapers' War.

Key words: Baroque Period, Theatre, Pamphlets, Propaganda, The Catalan Revolt. 
Conxita Domènech

Loa de la comedia de Montjuïc: un diàleg bèl.lic entre Catalunya i Castella

Guerra de Papers, Guerra de la Ploma i Guerra de la Tinta són alguns dels títols emprats per a referir-se a la Guerra dels Segadors (1640-1652): una guerra moderna en la qual els fulls impresos serveixen d'arma bèl.lica per a combatre l'enemic. Catalunya i Castella no només posen en marxa una maquinària armada sinó que també emprenen una maquinària propagandística i ideològica. Nombrosos discursos, relacions, sermons, pregons, avisos, cartes, cançons i poemes en català i en castellà s'escriuen durant els dotze anys de guerra. La Proclamación Católica a la Magestad Piadosa de Felipe el Grande (1640) - memorial de greuges escrit en castellà per a enviar-se i per a ser entès a Madrid — del frare agustí Gaspar Sala i Berart (I605-1670) inaugura la batalla propagandística. Francisco de Rioja (1583-1659) s'encarrega de contestar el memorial de greuges amb l'Aristarco o censura de la Proclamación católica de los catalanes (I64I). Continuen la contesa propagandística Francisco de Quevedo (I580-I645), ${ }^{1}$ José Pellicer y Tovar (I602-I679) i Alexandre Domènec de Ros (I598-I656), ${ }^{2}$ tots ells del bàndol filipista, i Francesc Martí i Viladamor (I6I6-I689) i Josep Font (s. XVII), entre altres, ${ }^{3}$ del bàndol català. Als tractats filosòfics, teològics i polítics dels autors anteriors s'afegeixen pamflets més assequibles per a un públic general. ${ }^{4}$

De teatre profa, durant els anys de la guerra, també n'hi haurà de dos tipus: el teatre culte de Francesc Fontanella (I622-1683/I685) i l'obra anònima de caràcter històric intitulada La comedia del marqués de los Vélez (I64I). Malgrat les diferències entre la primera obra dramàtica de Fontanella, Tragicomèdia pastoral d'amor, firmesa $i$ porfia (1642), i l'obra de l'autor anònim —-la primera escrita en català amb la finalitat de ser representada davant un públic distingit, la segona escrita en castellà amb alguns versos en català i probablement amb la finalitat de ser llegida a un públic popularambdues constitueixen espectacles complets: Amor, firmesa i porfia consta d'una peça dramàtica de tres actes, una lloa, un entremès i balls, i La comedia del marqués de los Vélez consta d'una peça dramàtica de tres actes, una lloa, un entremès i un ball.

La poca informació sobre La comedia del marqués de los Vélez s'extreu de l'obra mateixa i a partir de les còpies conegudes que se'n conserven: còpies impreses com la que pertany a la Col-lecció Bonsoms de la Biblioteca de Catalunya i que inclou sols la peça dramàtica de tres actes; i una còpia manuscrita que pertany a l'Arxiu Històric de la Ciutat de Barcelona i que inclou la peça dramàtica de tres actes, la lloa, l'entremès

I. Vegeu La rebelión de Barcelona ni es por el güevo ni es por el fuero (164I).

2. Vegeu Idea del Principado de Cataluña: recopilación de sus movimientos antiguos y modernos y examen de sus privilegios (1642) de Pellicer y Tovar i Cataluña desengañada (I646) de Domènec de Ros.

3. Vegeu Manifiesto de la Fidelidad Catalana, Integridad Francesa, y Perversidad Enemiga de la justa conversación de Cataluña en Francia (164I) de Martíi Viladamor i Catalana justicia contra castellanas armas (164I) de Font.

4. Vegeu Plecs poètics catalans del segle XVII de la Biblioteca de Catalunya. 
i el ball. En aquest article analitzaré la lloa ubicada després de La comedia del marqués de los Vélez a l'Arxiu Històric de la Ciutat de Barcelona. ${ }^{5}$ Tenint en compte la ubicació i l'estil, es pot argumentar que l'autor mateix les va escriure totes dues amb la intenció que primerament fos representada o bé llegida la lloa i, a continuació, la comèdia. Pel que fa a la lloa, em dedicaré a l'autor anònim català, i concretament barceloní, que vindicarà la presa d'armes dels catalans, si bé ho farà en llengua castellana. A més, l'autor anònim escollirà el teatre - i no el pamflet propagandístic — per difondre la seva ideologia política. D'aquesta manera, la Loa de la comedia de Montjü̈c es converteix en l'única obra dramàtica breu catalana de caràcter propagandístic escrita en castellà sobre la Guerra dels Segadors.

La Loa de la comedia de Montjuïc segueix l'estil de les lloes barroques castellanes: breu, dialogada, amb poca acció i anunciadora de la comèdia que precedeix. La lloa exposa les raons de la guerra i funciona com a presentació de la comèdia, i alhora com a presentació de la Guerra dels Segadors. La guerra comença amb la comèdia i no amb la lloa; per això aquesta representa el preludi de la guerra. A la lloa, hi dialoguen dos personatges: Catalunya i Castella; o, més ben dit, Catalunya conversa amb una Castella arrogant que no troba paraules per a justificar les seves accions. Per exemple, a la pregunta de Catalunya sobre per què Felip IV (I605-I665) tracta malament els seus vassalls catalans, Castella respon: «No me entremeto en sus mandatos Reales» (6). Catalunya és la protagonista, la que obre i tanca la lloa, i la que dirigeix el diàleg. A diferència de Castella, que no pot expressar-se correctament, Catalunya demostra eloqüència amb la incorporació en el seu parlament d'una relació històrica sobre l'ajuda catalana a Castella. Aquesta relació històrica en forma de monòleg (3) comença l'any 732:

\footnotetext{
El año treynta y dos y siete cientos

Barcelona a los Godos desterrados

dio amparo quando en Arabes sangrientos,

Julian quitó a Rodrigo honor y Estados.
}

I arriba al regnat de Felip IV. La relació històrica comprèn la meitat de la lloa - la lloa consta de sis pàgines en total i la relació històrica de tres. Un cop s'ha fet una revisió acurada dels monarques catalans que han ajudat Castella i de declarar les injustícies comeses pels castellans, la comèdia pot començar amb un clar presagi de victòria catalana: «Echada está la suerte, mas ¿qué es esto?» (7). Els clarins i les caixes

5. El ms. B-I5O (AHCB) consta de quatre folis ben conservats. 
Conxita Domènech

Loa de la comedia de Montjuïc: un diàleg bèl.lic entre Catalunya i Castella

donen pas a la comèdia: «Tóquense clarines, caxas, y suenen pieças, con que se empieça la Comedia, desaparecen Cathaluña y Castilla» (7).

LOA DE LA COMEDIA DE MONTJUÏC O LOA DE LA COMEDIA DEL MARQUÉS DE LOS VÉLEZ?

Gran part de les lloes o bé porten el mateix títol de la comèdia que precedeixen o bé no tenen títol. Aquest no és el cas de la Loa de la comedia de Montjuïc. Segons sembla, no hi ha una Comedia de Montjü̈c o almenys no se n'ha preservat cap còpia. Això no vol dir que aquesta lloa no estigui lligada a cap comèdia. M'inclino a pensar que la Loa de la comedia de Montjuïc està unida a La comedia del marqués de los Vélez per tres raons. En primer lloc, i com afirmava prèviament, la lloa es troba justament després de La comedia del marqués los Vélez. La segona raó és la incorporació de Montjuïc al títol complet de la comèdia: La famosa comedia de la entrada del marqués de los Vélez en Cataluña, rota de las tropas castellanas y asalto de Montjü̈c. Finalment, la lloa i la comèdia comparteixen estil i semblen escrites pel mateix autor. La comedia del marqués de los Vélez segueix els recursos del teatre barroc castellà - la incorporació del graciós, la dona disfressada d'home i la boda final—, i l'argument explica l'avenç militar del marquès de los Vélez (I602-I647). L’avenç militar castellà comença a Tortosa, passa per Cambrils, per Martorell i per moltes més localitats i finalitza a Barcelona, concretament a la muntanya de Montjuïc. Aquest avenç militar dóna títol a la comèdia però no s'inclou ni a la lloa ni al títol d'aquesta.

El marquès de los Vélez és el protagonista de gairebé tota la comèdia, però al final de la tercera jornada el reialista perdrà protagonisme. L'obra finalitza amb el triomf dels catalans a Montjuïc, amb la derrota del marquès de los Vélez, és a dir dels castellans, i amb el casament dels dos personatges ficticis. L'autor anònim intitula l'obra a partir del recorregut del marquès de los Vélez que comença amb «entrada» $i$ acaba amb «Montjuïc». El marquès de los Vélez deixa la cort o el centre per anar a Catalunya o la periferia. Ara bé, amb la batalla de Montjuïc i amb la victòria catalana, la perifèria o Catalunya es converteix en el centre, i el centre neuràlgic passa a ser Montjuïc. El protagonisme dels personatges també canvia: mentre la comèdia es titula a partir del personatge principal, al final de l'obra i a la tercera jornada el marquès de los Vélez queda oblidat i es concedeix el protagonisme a Pau Claris (I586-I64I). El president de la Generalitat de Catalunya restableix l'ordre, casa els personatges ficticis, reemplaça el marquès de los Vélez i les seves paraules clouen la comèdia (I64I: 26): 
Catalanes tremolad

estas ganadas banderas,

y hazaña tan inmortal

en bronzes se legalize,

perdonen si faltas ay.

La lloa anticipa el final de la comèdia i el triomf català a la muntanya de Montjuïc (6-7):

Buelve la vista a aquel cristal luziente

que retrata sucesos venideros,

mira sobre Monjuych, monte eminente,

hechos corderos tus leones fieros.

A la lloa no hi apareix el marquès de los Vélez, però sí que hi ha un recorregut, que és més cronològic que geogràfic. Aquest recorregut cronològic, que recorda el trajecte del marquès de los Vélez a la comèdia, es fa a partir de la relació històrica i s'ocupa dels diners, de les tropes, de les galeres, dels cavalls i de les armes que Catalunya ha ofert a Castella. El seguiment històric es realitza amb un llistat dels reis de la Corona d'Aragó, i s'inicia amb Alfons II (II57-II96). L'aportació dels catalans durant el regnat de Pere II (II77/II78-I2I3) és de «sesenta cavallos dos mil hombres / y... once galeras» (4). A Jaume I el Conqueridor (I208-I276) «todos los Catalanes le siguieron, / y Valencia al santo Principe rindieron» (4). Continuen Pere III (I24O-I285), Alfons III (I265-I29I), Jaume II (I267-I327), Martí I (I356-I4IO) i Alfons V (I396-I458). Gràcies a les gestions dels catalans, Carles de Viana (I42I-I46I) és alliberat de la presó pel seu pare, Joan II (I398-I479). Aquest darrer rebrà de Catalunya dues galeres, Ferran II (I452-I516) obté dos-cents quintars de pólvora, a Carles V (I500-I558) «dio [Catalunya]» dotze canons, a Felip II (I527-I598) «dio librança» trenta mil escuts «y al gran Filipo que oy govierna el mundo, / millon y medio lo que le dio alcança» (6).

El recorregut geogràfic de la comèdia, que comença a Tortosa i acaba a Barcelona, s'abandona a la lloa. A la Loa de la comedia de Montjuïc no s'adverteix el recorregut geogràfic perquè l'únic lloc presentat és la muntanya de Montjuïc. La lloa es situa a Montjuïc, al centre mateix, i des del centre es realitza el recorregut cronològic amb la relació històrica que inclou el llistat de monarques. Aquest recorregut també finalitza amb la batalla de Montjuïc i amb Felip IV. A la lloa no s'adverteix una direcció, ni de fora a dintre, ni del centre a la perifèria ni s'entra a Catalunya. La lloa ja està situada a Catalunya, i des de Catalunya s'efectua el recorregut per la història de Catalunya. Encara que la lloa sembla presentar La comedia del marqués de los Vélez, realment el que mostra és el triomf català, i en concret el triomf català a la batalla de Montjuïc. 
Conxita Domènech

Loa de la comedia de Montjuïc: un diàleg bèl.lic entre Catalunya i Castella

Per això, l'autor anònim encerta amb el títol de la lloa i no la titula Loa de la comedia del marqués de los Vélez sinó que la titula com la batalla que els catalans han guanyat al final de la comèdia: Loa de la comedia de Montjuïc.

\section{UN DRAMATURG CATALÀ AMB UNA LLOA ESCRITA EN CASTELLÀ}

No es pot esbrinar cap informació personal de l'autor anònim mitjançant la lectura de la comèdia. Dedueixo que l'autor és català perquè escriu en llengua catalana i en llengua castellana; també per la seva ideologia, que palesa amb l'odi als castellans i sobretot al marquès de los Vélez, a qui considera representant de la crueltat castellana. Encara que escriu majoritàriament en castellà no sembla que ho faci perquè aquesta llengua li resulta més facil, sinó pel desig d'una major difusió. Que domina el català, ho demostra quan Aminta, la criada, imparteix una classe de llengua catalana a Doblón, el criat (I64I: II):

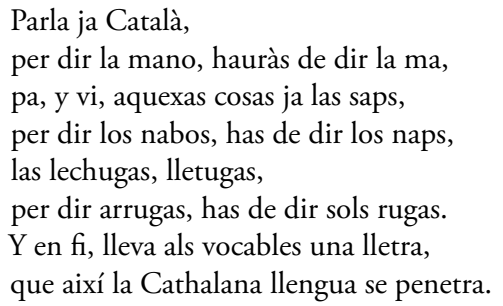

Aquesta no és l'única ocasió en què l'autor anònim introdueix la llengua catalana a la comèdia: també parla català l'almogàver. En canvi, els senyors i els polítics catalans, com ara Pau Claris, s'expressen sempre en castellà. Sembla absurd que un dramaturg que parla català i que defensa els catalans obligui Pau Claris a expressar-se en castellà en la seva comèdia. Connecto l'ús de la llengua castellana amb el caràcter informatiu de la comèdia. A l'autor anònim li interessa que catalans i castellans observin a través del seu teatre la crueltat castellana i la valentia catalana, i no descarta la possibilitat que l'obra arribi a «Reynos estraños..., en particular... la Corona de España» (I64I: I). De la mateixa manera que Sala i Berart, Martí i Viladamor i Font escriuen en castellà per comunicar el seu descontent a la Cort, l'autor anònim anuncia el seu descontent a un públic variat català i castellà a través del gènere dramàtic. A la comèdia, les parts informatives s'escriuen íntegrament en castellà i el català només es destina als personatges ficticis i a les descripcions d'allò que es considera propi català, com ara la classe de llengua de l'Aminta i la valentia demostrada per l'almogàver. 
Per a l'autor anònim, l'almogàver capturat pels castellans posseeix una característica innata de la naturalesa catalana: la valentia. ${ }^{6}$ El parlament de l'almogàver demostra la separació de les dues llengües emprades en la comèdia. Per una part, el contingut descriptiu és en català; per una altra part, el contingut informatiu és en castellà (I64I: I4; el subratllat és meu):

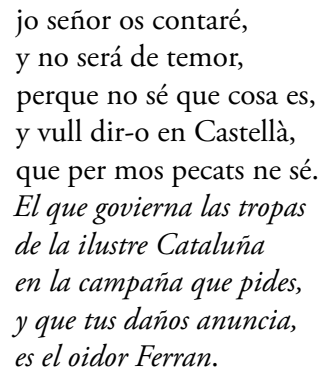

Així doncs, el motiu de l'ús del castellà per part de l'almogàver — personatge que s'encarrega de narrar la resistència de Martorell— sembla ser el mateix de l'autor anònim: informar. Dramaturg i personatge comparteixen anonimat, no se sap el nom de cap dels dos, parlen català i castellà, i trien la llengua castellana per divulgar els successos que estan esdevenint-se a Catalunya.

El caràcter informatiu és més patent a la lloa. No s'hi inclouen personatges ficticis ni tampoc s'hi integren personatges històrics — s'esmenten diversos personatges històrics, però cap d'ells participa en el diàleg. Els dos únics personatges són al.legòrics, i el diàleg que mantenen és informatiu, i fins i tot històric. Encara que la lloa és propagandística i gens objectiva, cal afirmar que és de caràcter informatiu i la ficció no hi té cabuda. És per aquesta raó que la lloa no incorpora el català, i Catalunya i Castella només parlen en castellà. A més a més, l'autor té com a objectiu fer el diàleg més versemblant i òbviament Castella no parla català.

L'autor anònim domina el català i també coneix la literatura catalana, o si més no coneix la poesia del Rector de Vallfogona (I582-I623), a qui considera un visionari. El pròleg de la comèdia finalitza amb la inclusió de dues dècimes extretes del «Desengany del món». Ara bé, el dramaturg sobretot demostra un bon coneixement del teatre barroc castellà: la seva comèdia seguirà tot allò que estava de moda a les peces castellanes de l'època. A més dels elements esmentats anteriorment - la incorporació del graciós, la dona disfressada d'home i la boda final—, els personatges ficticis tenen

6. La catalanitat i la valentia s'associen durant tota la comèdia: «per ser català, i per ser valent» (I64I: II).

Caplletra 60 (Primavera, 2016), pp. 15-29 
Conxita Domènech

Loa de la comedia de Montjuïc: un diàleg bèl.lic entre Catalunya i Castella

noms de comèdia castellana: cal esmentar el nom d'Aminta que recorda la camperola d'El burlador de Sevilla (1630) de Tirso de Molina (I579-I648). L'únic personatge fictici castellà és el criat - tots els altres són catalans. Com a bon criat i graciós, el seu nom denota una característica pròpia del personatge, i com a bon castellà, el seu nom denota la imatge que Castella oferia als catalans: el criat avar amb intenció d'enriquir-se a Barcelona es diu Doblón.

Encara que no és propi del teatre castellà, l'autor anònim dóna sovint instruccions per a la representació, i la didascàlia de la comèdia incorpora una tramoia en la qual apareix Santa Eulàlia. Finalment, el dramaturg no s'oblida d'incorporar el tema recurrent del teatre castellà: l'honor. Així i tot, la incorporació del tema de l'honor a la comèdia sembla una incorporació gratuïta. El personatge fictici principal, don Carlos, mata el germà de la seva promesa per qüestions d'honor, sense que tinguen cap notícia prèvia ni del germà ni de les causes del duel. Juntament amb el tema de l'honor, la disfressa masculina de la protagonista apareix com un afegit. L'autor anònim, influenciat pel teatre castellà, no pot oblidar-se del tema més repetit d'aquest teatre ni de les paraules de Félix Lope de Vega a El arte nuevo de hacer comedias en este tiempo: «porque suele / el disfraz varonil agradar mucho» (2006: I46). L'autor anònim podia conèixer el teatre barroc castellà de dues maneres. D'una banda, podia haver llegit les comèdies castellanes. Albert Rossich apunta que durant el segle xvir neix el costum de llegir peces teatrals (200I: 57). D'altra banda, podia ser un assidu espectador del teatre de la Santa Creu de Barcelona on es representaven les comèdies castellanes més famoses.

Lautor anònim també coneix els successos que ocorren durant la guerra. Està ben informat sobre les batalles a Cambrils, a Tarragona i a Martorell, i sens dubte, sobre la batalla a Montjuïc. A la comèdia explica amb detall els esdeveniments de Cambrils del is de desembre de 1640 i l'execució de més de sis-centes persones, incloent-hi les morts a garrot vil dels cònsols de Cambrils: el baró de Rocafort, Carles Bertrolà i Jacint Vilosa. La batalla de Montjuïc la coneix perquè l'ha viscuda a la seva ciutat —m'encarregaré de Barcelona i de l'autor anònim en els apartats següents. No se sap si el dramaturg participa a la batalla de Montjuïc, però ben segur que en coneix els detalls, i ho demostra incorporant aquesta batalla a la lloa i a la comèdia. De Tortosa, de Cambrils, de Tarragona, de Martorell i d'altres localitats probablement està informat gràcies als pamflets que es distribuïen per Catalunya durant la Guerra dels Segadors. Jaume Romeu, Jaume Matevat i Gabriel Noguers són els impressors catalans que publiquen la majoria de pamflets propagandístics de la guerra i tant la comèdia com la lloa seran impreses a l'establiment del primer. De fet, m'atreveixo a afirmar que l'autor anònim podria haver escrit algun pamflet de la guerra per a aquests impressors, i concretament per al primer d'ells, Jaume Romeu. A més a més

Caplletra 60 (Primavera, 2016), pp. 15-29 
de tots els elements que la comèdia i els pamflets de guerra tenen en comú, el disseny i els gravats de la portada de La comedia del marqués los Vélez i de Relació en rima de Jaume Roig, de tot lo que ha succehit dintre, y fora de Perpiñà (1642) són idèntics, ${ }^{7}$ i és clar tots dos impresos per Jaume Romeu. ${ }^{8}$

La comedia del marqués los Vélez s'estructura a partir de quatre relacions, que anomenaré relacions dramàtiques. Aquestes — les batalles de Cambrils, de Tarragona, de Martorell i de Barcelona- s'integren a la comèdia amb el relat dels successos històrics, d'una manera abrupta perquè s'hi incorporen les relacions de les batalles a la manera pamfletària. Dintre d'aquestes relacions dramàtiques, l'autor anònim descriu amb detall personatges històrics, per exemple: «El uno es Baltasar Càrcer, / don Antonio Meca ayuda» (I64I: I4); ${ }^{9}$ i informació militar, per exemple: «Su ejército en Cambrils fiero presenta / de quince mil infantes, / y cuatro mil caballos» (I64I: 3). Per tal de fer-ne una descripció detallada, abandona les eines dramàtiques i empra les eines pamfletàries. Per un costat, elimina el diàleg i un sol personatge exposa la relació completa. Per l'altre, s'agreguen elements que pertanyen al gènere pamfletari de la guerra: símbols, sants i enumeracions, seguint sempre una mateixa organització. Un exemple dels símbols més emprats és la descripció dels castellans com a llops disfressats de corders o d'ovelles. A la comèdia, l'almogàver declara que el marquès de los Vélez "ve en forma de corder, / y per dintre és un llop» (I64I: I4), i al pamflet intitulat Carta que ha enviada la vila de Perpinyà a Cathalunya (164I), els castellans van «ab vestiments de ovelles, / que són uns llops afamats» (1988: 98). Altres símbols catalans, castellans i francesos són les barres catalanes i les torres castellanes («y que las altas barras Catalanas / abaten ya tus torres Castellanas», 7), els lleons («hechos corderos tus leones fieros», 7), i la flor de lis («la flor de Lis a vientos lisonjeros», 7). Pel que fa als sants, santa Eulàlia sempre hi té el protagonisme quantitatiu i qualitatiu. Sant Policarp i santa Eulàlia es troben a la comèdia i a la Resposta que fa Cathalunya a una carta que li ha enviada la vila de Perpinyà (I64I): «Policarpo y Eulalia, / y lo pastor sant Olaguer, / tornaren per Barcelona» (1988: 130).

Deixo de banda els sants per passar a les nombroses enumeracions que apareixen als pamflets, a la comèdia i a la lloa. Les enumeracions més reiterades són de capitans $\mathrm{i}$ de generals. A la famosa victoria que han alcansada dels enemichs los tèrcios de infanteria

7. Aquest fullet i els altres que menciono més endavant es troben a Escobedo (I988).

8. Els gravats que apareixen a les portades dels plecs solts s'utilitzaven repetidament en diferents impresos. Els gravats eren indicacions emblemàtiques del tipus de temàtica que es tractava a l'imprès.

9. Baltasar Càrcer fou un dels cavallers que ajudava el diputat militar Francesc de Tamarit (I600-I653). No estava a càrrec de soldats, però aconsellava el diputat, animava els soldats i proporcionava munició. Antonio Meca fou coronel i assistent del conseller Joan Francesc Rossell.

Caplletra 60 (Primavera, 2016), pp. 15-29 
Conxita Domènech

Loa de la comedia de Montjuïc: un diàleg bèl.lic entre Catalunya i Castella

y cavalleria catalana y francesa (I64I) repeteix alguns dels noms de la comèdia: «Roger, Vilallonga, Càrcer, ${ }^{10}$ / Reguer, Ycart, Cortich, Bosch,...» (1988: I2I). D'especial interès a la comèdia és l'enumeració dels gremis de la ciutat de Barcelona «Sastres, Zapateros, Cajoneros / Pieleros, Taberneros,...» (I64I: I2I). L'autor anònim esmenta més de vint gremis i confraries que ajuden la ciutat de Barcelona contra l'atac castellà. A la lloa, l'enumeració és dels reis i prínceps de la Corona d'Aragó. Amb aquestes enumeracions, l'autor anònim demostra el coneixement actual i històric de Barcelona i de Catalunya. Pel que fa a l'organització, les relacions dramàtiques inserides a la comèdia segueixen una estructura similar a fullets tal com Carta que ha enviada la vila de Perpinyà a Cathalunya. La carta comença amb una breu introducció, seguida per una descripció de la crueltat dels castellans, passa al relat de l'alçament, continua amb l'aparició dels francesos, s'anuncia l'ajuda divina i acaba amb un curt acomiadament.

\section{ELS DOS PERSONATGES DEL PAMFLET DRAMÀTIC: CATALUNYA I CASTELLA}

Els personatges de la comèdia i de la lloa no són els mateixos. La comèdia posseeix una varietat extraordinària de personatges; dintre d'aquesta varietat es fan dues separacions: els personatges ficticis que es diferencien dels històrics (don Carlos és fictici i Pau Claris és històric) i els catalans que es diferencien dels castellans (Aminta és catalana i Doblón és castellà). A la lloa no hi ha ni personatges ficticis ni personatges històrics, tan sols hi ha dos personatges al-legòrics (el català és Catalunya i el castellà és Castella). La manca de ficció s'enllaça amb la manca d'entreteniment. A la comèdia els personatges ficticis s'incorporen per treure-li gravetat a l'obra i perquè l'espectador o el lector gaudeixi d'uns moments de diversió. Per exemple: la covardia del criat castellà, Doblón, podria provocar les rialles de l'espectador o del lector. Aquests moments no són necessaris a la lloa pel seu objectiu i per la seva brevetat. Divertir no és l'objectiu de l'autor anònim a la lloa; tot el contrari, a ell l'interessa informar dels abusos castellans. Mentre La comedia del marqués de los Vélez es podria definir com quatre relacions dramàtiques introduïdes en una trama fictícia farcida dels convencionalismes de la comedia nueva castellana, la Loa de la comedia de Montjuïc seria una espècie de pamflet dramàtic. Aquest pamflet és dramàtic perquè l'autor anònim fa ús del diàleg. El diàleg, per cert, és molt bàsic, i Castella es limita a contestar-hi breument a Catalunya o a fer-li una pregunta curta perquè Catalunya elabori una resposta lúcida

Io. Vegeu la nota anterior sobre Baltasar Càrcer. 
i llarga. La resposta de Catalunya a la pregunta de Castella «Pues, ¿quándo Barcelona me ha servido?» (3) consta de tres fulls de matèria històrica. Catalunya es dedica a recordar tot allò que ha fet per Castella, o com la mateixa protagonista proposa, «fer-li memòria» de la història de Catalunya: «mas oye ya la Catalana gloria, / que un ingrato es muy flaco de memoria» (3). En resum, Catalunya acusa Castella, respon les seves preguntes concises i relata una memòria històrica.

L'oralitat també connecta la lloa amb els fullets propagandístics. Joana Escobedo assegura que els fullets poètics de la guerra eren distribuït pels llibreters o pels seus intermediaris i divulgats per cantaires o per recitadors ambulants (I988: XIV). L'element oral que anota Escobedo es fa patent en nombrosos fullets: Relació en rima de Jaume Roig, de tot lo que ha succehit dintre, y fora de Perpiñà (I642) comença amb «estau atents / al relatar, / que us vull comptar» (1988: I48) i Cópia de una carta; que envia Simon Verges (I642) s'inicia amb "compta un succés /... que ha succehit» (I988: 160). El mateix element oral dels fullets s'incorpora a la Loa de la comedia de Montjuïc: «mas oye ya la Catalana gloria» (3), i corrobora el to pamfletari d'aquesta, la qual sembla un pamflet propagandístic distribuït pel llibreter i cantat per un recitador ambulant, amb la sola diferència de la forma dialogada. Així i tot, el diàleg o l'intent de diàleg és freqüent als pamflets. A Carta que ha enviada la vila de Perpinyà a Cathalunya, el remitent, Perpinyà, saluda el destinatari, Catalunya, proposant un diàleg entre ells: «A sa mare Cathalunya / Desitja salut, y gràcia» (1988: 97).

\section{UNA LLOA DOCUMENTADA A L'ARXIU DE BARCELONA}

Tant a la comèdia com a la lloa, l'autor anònim demostra que està ben informat: les dècimes del Rector de Vallfogona apunten que llegeix poesia de l'època; el llistat de reis suposa que coneix la història de Catalunya; les descripcions de les batalles indiquen que està al corrent dels successos de la guerra. A la comèdia, els versos del Rector de Vallfogona, les parts escrites en català i l'odi als castellans assenyalen que l'autor és català. Encara que l'odi cap al castellà també s'observa a la lloa, tota la peça breu està escrita en castellà i no hi ha referències a cap escriptor català. La brevetat de la lloa semblaria aportar menys informació personal que l'exposada a la comèdia, però a la lloa hi ha una indicació clau que situa l'autor anònim a la ciutat de Barcelona: «lo que el Archivo de mi Ciudad enseńa» (4, el subratllat és meu). Certament, l'autor anònim no afirma que «mi Ciudad» sigui Barcelona, ara bé, dos versos després apareix Barcelona, i aquesta ciutat apareixerà en diverses ocasions a la lloa. 


\section{Conxita Domènech}

Loa de la comedia de Montjuïc: un diàleg bèl.lic entre Catalunya i Castella

Amb «lo que el Archivo de mi Ciudad enseña», l'autor anònim no només expressa la seva procedència, sinó que també assegura que elabora un treball documentat, i que la seva peça dramàtica no pertany a un aficionat, tot el contrari, ell és un historiador. El llistat de reis i la informació sobre les aportacions catalanes a Castella no són inventades, l'autor anònim ha emprès tota una tasca de recerca, i perquè en quedi constància, l'esmentarà dues vegades (5):

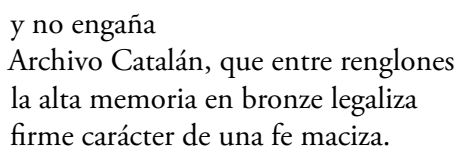

El mateix concepte de la serietat del treball es troba en un document escrit pel seu impressor, Jaume Romeu, qui assegura: «que yo no só pas copiador, sinó historiador, lo qual no està obligat escríurer las arengas enteras» (1993: 27). Henry Ettinghausen assenyala que la labor de Jaume Romeu era proveir material per a futurs historiadors, i en paraules de Jaume Romeu, "perquè... [els futurs historiadors] vàjan segurs y advertits» (1993: 23). Dramaturg i impressor utilitzen la recerca per a desenvolupar una feina acurada, $i$ tots dos esdevenen els protagonistes d'una nova era informativa: en el cas de Jaume Romeu, s'establirà com un dels fundadors del periodisme modern a la península Ibèrica; en el cas del dramaturg, s'establirà com un informador escènic dels abusos comesos durant la guerra, és a dir, com un autor de teatre de denúncia o de teatre de guerra.

El material que extreu de l'arxiu és la llista de reis i de tot allò que Catalunya ha ofert a Castella. A part dels personatges històrics, l'autor anònim inclou dos personatges del seu temps. Els personatges més repetits als fullets poètics (I988: 215), com ara la Glosa Cathalana (I64r?), eren el rei Felip IV, el comte-duc d'Olivares (I587-I645) i el protonotari Villanueva (1587-1653):

$\begin{array}{lll}\text { Diuse que lo Compte Duc } & \ldots \ldots . & \text { Un ruc } \\ \text { y la Real Magestat } & \ldots . . . & \text { Un fat } \\ \text { y lo seu Protonotari } & \ldots \ldots . & \text { Sectari. }\end{array}$

I, tanmateix, l'autor anònim es val del rei - ja mencionat en apartats anteriorsi del comte-duc o «Privado» com ell l'anomena (3):

Pues así pones en infame olvido tantas finezas tú, Castilla, agora, por un Privado que un Sejano a sido, por quien España, como Roma llora. 
No tot a la lloa és material d'arxiu: l'autor anònim també hi exposa les raons de la guerra per Castella i per Catalunya, i per descomptat, les raons castellanes no són vàlides i són refutades amb facilitat. Segons l'autor anònim, els castellans no juguen net i les seves tàctiques són el suborn i el terror (2-3):

Cath. Sus Privilegios juró el Rey, y abona a Barcelona, quando así procura conservar lo que han dado a sus mayores tantos Monarcas, Reyes y seńores.

Casti. ¿Jurólo? Juró mal, y a de enmendarlo.

Cath. ¡No sé como podrà, siendo perjuro!

Casti. ¿Dotores faltarán para apoyarlo?

Cath. Que estarán sobornados conjeturo, o llenos de temor, han de aprovarlo; mas no por eso el Rey está seguro.

\section{LA LOA DE LA COMEDIA DE MONTJUÏCCOM UN MEMORIAL HISTÒRIC}

La Loa de la comedia de Montjuïc i La comedia del marqués de los Vélez poden donar una primera impressió de mer espectacle d'entreteniment, i potser a la comèdia, amb la trama fictícia, aquesta impressió es fa fins i tot més patent. Anteriorment, i citant Albert Rossich, apunto que al segle Xvir neix el costum de llegir peces teatrals; Albert Rossich utilitza un fragment del text de Josep Boneta per a corroborar aquest nou costum. Utilitzo el mateix fragment (Boneta 1955: 17) però per provar que les comèdies es llegien com activitat d'esbarjo:

fué un varón espiritual a visitar a otro que estaba enfermo. Y como lo hallase leyendo un libro de comedias y se escandalizase, se excusó diciendo: - ¿Qué quieres? Si no me encargan otra cosa los médicos, sino que me divierta-.

L'entreteniment, sens dubte, està present a la lloa i a la comèdia. Ara bé, vull fer ressaltar que la intenció principal de l'autor anònim és informar a partir de fonts fidedignes.

La lloa i la comèdia també fan una impressió de caràcter popular, i per aquest fet, s'enllacen amb els fullets poètics. En el cas dels darrers, Joana Escobedo apunta «no oblidem la seva vessant popular» (I988: Xv). Potser per aquesta vessant popular, la lloa i la comèdia estan carregades dels mateixos símbols disposats als fullets poètics (barres, corders disfressats de llops, torres, lleons i flors de lis). No obstant això, la gran diferència és que molts fullets poètics estan escrits en català, la lloa està escrita en 


\section{Conxita Domènech}

Loa de la comedia de Montjuïc: un diàleg bèl.lic entre Catalunya i Castella

castellà i la comèdia està escrita en més castellà que català, i per descomptat, la llengua emprada va lligada al públic a qui es destina l'obra. El castellà s'entenia a les ciutats grans, però en els pobles petits hi havia persones que no l'entenien i en conseqüència, Pere Gil (I55I-I622) decideix escriure el seu llibre en català (Iglésies 2002: 328):

\footnotetext{
Alguns per ventura judicaran que en aquest temps no era necessari imprimir-se lo present llibre en esta llengua, puis la castellana, dita ja espanyola, és casi universalment entesa. Però com se veja i toque ab les mans que, exceptades algunes poques ciutats, com són Barcelona, Tarragona, Gerona, Tortosa i Lleida, i algunes poques viles, com Perpinyà, Vilafranca del Penedès, Cervera, Tàrrega, Fraga, Montsó i semblants, que estan en camins reals, en les altres demés ciutats, viles y llochs no és ben entesa la llengua castellana de la gent comuna, i ningunes dones la usen..., per ço me ha paregut ser de glòria de Déu vertit est llibre en les paraules més planes i comunes de la llengua catalana per a que tota manera de gent puga d'ell aprofitar-se.
}

Si el propòsit de l'autor anònim és només encendre els ànims dels catalans, òbviament s'equivoca de llengua. Sí que s'hi inclouen els símbols populars dels fullets, però igualment la lloa està carregada de referències mitològiques i bíbliques, per exemple: «tu Barcelona, o Cathaluña es esa, / que a de provar olvidos del Leteo» (2), que sens dubte no entenia la majoria de la població.

En definitiva, l'autor anònim es val de tots els recursos disponibles: de la comedia nueva castellana s'apodera de noms dels personatges, de temes i de convencionalismes; de l'arxiu català obté informació històrica de reis i d'aportacions de Catalunya a Castella; dels fullets poètics adquireix símbols, sants, enumeracions i organització; de les relacions extreu les batalles que estan succeint a Catalunya; de la mitologia i de la Bíblia s'apropia de referències pretèrites per connectar-les amb les circumstàncies actuals. Tot això es duu a terme per a informar, i com declara el seu impressor Jaume Romeu, no sols els catalans i els castellans de l'època, sinó també per a deixar constància d'uns fets per als futurs lectors. És més, l'autor anònim creu en la memòria històrica i, per tant, consulta l'arxiu de Barcelona. En tot moment és conscient d'aquesta memòria i l'anomena repetidament a la lloa: «la alta memoria en bronze legaliza» (5). Les mateixes paraules apareixen a la cloenda de la comèdia: «y hazaña tan inmortal [la batalla de Montjuïc] / en bronzes se legalize» (I64I: 26); així doncs, no cal repetir-ho més, la voluntat de l'autor anònim és reconèixer públicament la batalla de Montjuïc.

Conxita Domènech University of Wyoming cdomenec@uwyo.edu 


\section{REFERÈNCIES BIBLIOGRÀFIQUES}

Boneta, J. (1955) Gracias de la Gracia: saladas agudezas de los santos, Barcelona, Editorial Casulleras.

Escobedo, J., ed. (I988) Plecs poètics catalans del segle XVII de la Biblioteca de Catalunya, Barcelona, Biblioteca de Catalunya.

Ettinghausen, H. (1993) La Guerra dels Segadors a través de la premsa de l'època, Barcelona, Curial.

La famosa comedia de la entrada del Marqués de los Vélez en Cataluña, rota de las tropas castellanas y asalto de Montjuïc (I64I), Barcelona, Jaume Romeu.

Font, J. (I64I) Catalana justicia contra las castellanas armas, Barcelona, Jaume Matevat.

Fontanella, F. \& J. Ramis i Ramis (1982) Teatre barroc i neoclàssic, ed. de MariaMercè Miró i Jordi Carbonell, Barcelona, Edicions 62.

IglÉsies, J. (2002) Pere Gil, S.I. (I5SI-I622) i la seva geografia de Catalunya: seguit de la transcripció del Libre primer de la historia Cathalana en la qual se tracta de historia o descripción natural, ço es de cosas naturals de Cathaluña, Barcelona, Societat Catalana de Geografia.

Loa de la comedia de Montjü̈ (I64I), Barcelona, Jaume Romeu.

Lope De Vega, F. (2006) Arte nuevo de hacer comedias, ed. d'Enrique García SantoTomás, Madrid, Cátedra.

Molina, T. DE (2007) El burlador de Sevilla, Madrid, Cátedra.

Pellicer y Tovar, J. (1642) Idea del Principado de Cataluña: recopilación de sus movimientos antiguos y modernos y examen de sus privilegios, Amberes, Geronimo Verdus.

Quevedo y Villegas, F. de (I96I) Obras completas: Obras en prosa, ed. de Felicidad Buendía, Madrid, Aguilar.

Rioja, F. de (I640) Aristarco o censura de la Proclamación católica de los catalanes, Madrid.

Ros, A. de (1646) Cataluña desengañada, Nàpols, Egidio Longo.

Rossich, A., A. Serrà, P. Valsalobre \& D. Prats, eds. (200I) El teatre català dels orígens al segle XVIII, Kassel, Reichenberger.

Sala i Berart, G. (i640) Proclamación Católica a la Magestad Piadosa de Felipe el Grande, Barcelona, Jaume Matevat. 